\title{
Ending with World Destruction: a Closural Device in Lucretius' De Rerum Natura and its Influence on Later Latin Poetry
}

Manuel Galzerano

\begin{abstract}
This paper will investigate a well-attested closural device in Lucretius' De rerum natura: the recurrence of world destruction scenarios as the conclusion both to single literary passages and to single books. The argumentation will be divided into two parts. The former will examine the most important examples of this literary scheme in Lucretius' poem $(1.1104-1117 ; 2.1105-$ $1174 ; 6.596-607)$ and will define their models, their aim and their features. The latter will give some further examples of "apocalyptic" closures in Latin literature between I century BC and I century AD. The analysis of these passages will show the persistent presence of allusions to Lucretius' poem, considered as an indisputable auctoritas of cosmic eschatological poetry.
\end{abstract}

\section{Keywords}

Lucretius; De rerum natura; eschatology; cosmology; sublime; rhetoric; closure; Virgil; Manilius; Statius 


\section{Introduction}

This paper will investigate a well-attested closural device in Lucretius' poem: ${ }^{1}$ the recurrence of scenes of world destruction as the conclusion both to single books and to internal literary passages. ${ }^{2}$ In fact, Lucretius makes systematic use of this literary scheme, which clearly represents an essential feature of the De rerum natura. ${ }^{3}$ Moreover, as it will be shown, this Lucretian scheme will be massively influential on later Latin cosmic eschatological scenes.

\section{Eschatological conclusions in internal literary passages}

Lucretius largely uses the above-mentioned closural device in single literary passages, particularly in the last two books of the De rerum natura. A noticeable example appears in Book 5, vv. 351-379. Lucretius recapitulates the fundamental and eternal elements in Epicurean physics: atoms, void and universe (conceived as the sum of all, summarum summa). The conclusion of this recapitulation is devoted to the demonstration of the mortality of the world, which will scatter through the immense void that surrounds it (vv. 370-375):

nec porro natura loci spatiumque profundi

deficit, exspargi quo possint moenia mundi,

aut alia quavis possunt vi pulsa perire.

Haut igitur leti praeclusa est ianua caelo

nec soli terraeque neque altis aequoris undis,

sed patet immani et vasto respectat hiatus. ${ }^{4}$

As Charles Segal affirms, "the gate of death becomes virtually a living mouth, a huge gaping maw (vasto hiatus), endowed even with a kind of vision (respectat)». ${ }^{5}$ Thus, this recapitulatory passage ends up with the sublime image of the fierce jaws that are about to swallow the world, like a gate of death (ianua leti). ${ }^{6}$

1 As regards the question of closure in Greek and Latin literature, cf. Herrnstein Smith (1968); Fowler (2000: pp. 284-307); Fowler (1997: pp. 3-22); Hardie (1997: pp. 139-162). As regards Lucretius' De rerum natura endings, cf. Klingner (1952: pp. 3-30); Müller (1978: pp. 197-231); Brown (1987: pp. 47-100); P. Fowler (1997: pp. 112-138).

2 As Don Fowler points out, «the techniques of closure at these levels are mostly the same as those found at the end of individual works». Cf. Fowler (2000: pp. 246-247).

3 The examples chosen will include both passages where the catastrophe is alluded to and passages where it is directly described.

4 «Nor again is there any shortage of unfathomable space into which the ramparts of the world could be dispersed; or else they may be destroyed by the impact of some other force. Therefore the door of death, far from being closed against the sky or the sun or the earth or the deep waters of the ocean, stands wide open and confronts them with vast gaping jaws». Translation by Martin Ferguson Smith, which will be used throughout.

5 Cf. Segal (1990: p. 136).

6 The remaining four verses are a mere reformulation of the concepts developed through this passage, which allows a transition to the next argument. 
Even the eschatological section of Book 5 (vv. 91-415), considered as a whole, shows an apocalyptic ending. In fact, Lucretius closes this section with a literary passage (vv. 380-415) devoted to the description and explanation of the most terrible catastrophic phenomena caused by fire and water: the deluge and the conflagration (with relation to Phaeton's myth). Here, the reader feels the same sensation of imminent ruin - which is both threatening and fascinating, in a word, sublime - that he felt in the magnificent conclusion of the previous literary passage (5.370-375). In fact, according to Lucretius, these great catastrophes will inevitably return and lead the world to destruction: the fight between the most powerful elements will end with the ruin of the world. It's only a matter of time (vv. 380-387):

Denique tantopere inter se cum maxima mundi

pugnent membra, pio nequaquam concita bello,

nonne vides aliquam longi certaminis ollis

posse dari finem, vel cum sol et vapor omnis

omnibus epotis umoribus exsuperarint?

quod facere intendunt, neque adhuc conata patrantur

tantum suppeditant amnes ultraque minantur

omnia diluviare ex alto gurgite ponti. ${ }^{7}$

As regards Book 6, the closing section of Lucretius' treatment of earthquakes (vv. 535-607) depicts a seismic phenomenon that strikes the inhabitants of one or more cities (cf. 6.596 per urbis). The calamitous impact of this catastrophe persuades even those thinkers who maintain cosmic eternity to abandon their faith, accepting the mortality of the world. The passage culminates in an apocalyptic scenario, which represents the manifestation of a latent fear: the Earth seems to be devoured by an abyss, while everything turns into chaos (vv. 603-607 et fiat mundi confusa ruina).

\section{The eschatological conclusions of Book 1 and Book 2}

In Lucretius' poem, the scheme of the final catastrophe is not circumscribed to internal literary passages: in fact, even the first two Books of the De rerum natura end up with apocalyptic pictures.

The last section of Book 1 (vv. 1052-1113) is devoted to the refutation of an erroneous cosmological theory, defended by Lucretius' opponents (first of all, the Stoics). ${ }^{8}$ Far from confirming the eternal stability of the cosmos, this theory would condemn the world to an immediate dissolution: in fact, according to its physical premises, light and heavy elements would "escape" through the void, in opposite directions. The last verses

7 «Again, since the massive members of the world fight so furiously with one another, engaging in an unrighteous war, do you not see that some end may be assigned to their long struggle? It may be that the sun and every kind of fire will gain victory by drinking up all the waters. But in spite of their strenuous efforts to do this, they are not yet achieving their aim; for the rivers make up the supply of water and moreover threaten to inundate the whole world with a deluge from the unfathomable abyss of ocean». 
of this section - and of the entire $\operatorname{Book}^{9}$ - represent this hypothetical interitus mundi in a detailed way, culminating in the annihilation of the world (vv. 1102-1113):

ne volucri ritu flammarum moenia mundi

diffugiant subito magnum per inane soluta

et ne cetera consimili ratione sequantur

neve ruant caeli tonitralia templa superne

terraque se pedibus raptim subducat et omnis

inter permixtas rerum caelique ruinas

corpora solventes abeat per inane profundum,

temporis ut puncto nihil extet reliquiarum

desertum praeter spatium et primordia caeca. ${ }^{10}$

In a minimum of time (temporis puncto) the maximum possible destruction is caused. The world sinks into chaos and confusion (inter permixtas ruinas) and the poet paints «a dramatically bleak picture of the intentional and teleological emptiness of the universe: atoms flitting around randomly, moving without purpose, following their own laws of motion, but to end whatsoever». ${ }^{11}$

The last section of Book 2 (vv. 1105-1174) can be divided into two parts: the former (vv. 1105-1149) depicts the ageing process of the world, from aggregation to disaggregation; the latter (vv. 1150-1174) describes the senescence of the Earth, which is about to die, like an old woman. Both these parts end up with an apocalyptic scenario: in fact, the last image of the former part is the collapse and ruin of the cosmic walls (moenia mundi): sic igitur magni quoque circum moenia mundi / expugnata dabunt labem putrisque ruinas. ${ }^{12}$

Analogously, the last words of Book 2 powerfully resume that everything (included the world and the Earth) is doomed to death. Time will slowly bring everything to dissolution (literally, ad capulum, i.e. "to the coffin"): nec tenet omnia paulatim tabescere et ire / ad capulum spatio aetatis defessa vetusto. ${ }^{13}$

9 Verses 1114-1117 must be considered as a sort of coda, an autonomous final reassurance of the reader.

10 «To prevent the ramparts of the world from flying apart with the volatility of flames and being dispersed throughout the vast void. Everything else would suffer the same fate: the thunderous precincts of the sky would rush upward, the earth would suddenly withdraw from beneath our feet, and amid the commingled debris and disintegration of heaven and earth the whole world would disappear into the unfathomable void. Thus in an instant nothing would remain except deserted space and invisible atoms. For, in whatever part you suppose that matter first fails, that part will serve as a gate of death for the world through which the whole throng of matter will sally out».

11 Cf. Lehoux (2013: p. 148).

12 «In just the same way the ramparts that surround the mighty world will be taken by storm and will collapse and crumble into ruins».

13 «Only he fails to grasp that all things gradually decay and head for the reef of destruction, exhausted by long lapse of time». I do not agree with Smith's refusal of Vossius' conjecture ire ad capulum in favour of ire ad scopulum. The phrase ire ad capulum ("go to the grave") better suits the context: cf. Galzerano (2015: pp. 243-253). 


\section{The conclusion of Book 6: an eschatological interpretation}

Similar considerations can be made about the stark and dramatic conclusion of Lucretius' poem: the account of the Athenian plague. In fact, as Monica Gale points out, «like the opening invocation, the plague also has a number of symbolic functions and several layers of meaning». ${ }^{14}$ In my opinion, one of these layers of meaning is the depiction of

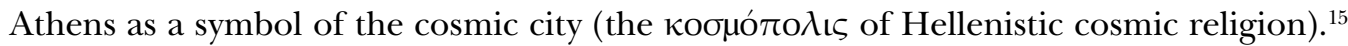
In fact, some Stoic passages demonstrate that, in the late-Hellenistic philosophical debate, the plague of Athens described by Thucydides was used as an exemplum both for the absence of providence ( $\dot{\alpha} \pi$ Qovonoí $\alpha)^{16}$ and for the corruptibility of the world. ${ }^{17}$ A fundamental source for these interpretations is Philo's treatise De providentia. In fact, Philo (prov. 1.17-19) shows that the corruptibility of the air (according to Lucretius, the cause of the plague, see 6.1119-1130) was considered as a proof of the mortality of the world and of its inevitable ageing process. Thus, the Athenian plague becomes also a real Epicurean myth, that «is transformed from a past event into a vehicle for meanings of universal and paradigmatic application». ${ }^{18}$ In effect, as well as Lucretius' opening exaltation of Venus genetrix may be considered as a representation of the first day of the world (the mundi tempus genitale diemque primigenum in 2.1105-1106), the conclusion of the poem may be read as a representation of the last day of the world. The final catastrophe will spare nobody, as underlined in the last verses of the poem: ${ }^{19}$ nec poterat quisquam reperiri, quem neque morbus / nec mors nec luctus temptaret tempore tali. ${ }^{20}$ Moreover, there is a strong connection between this ending and the final $\dot{\varepsilon} \pi \iota \varphi \omega \nu \eta \mu \alpha^{21}$ of Lucretius' Book 2, which similarly ends up with the representation of the path to the grave and a burial

14 Cf. Gale (1994: pp. 224-225).

15 In particular, the Lucretian Athens resembles the Middle Stoa kosmopolis. As J. Van Oort notes, «The only real polis is, according to the earliest Stoics (Zeno, Chrysippus), the heavenly one, a society of gods and (good) humans (...). In the Middle Stoa, with Panaetius and especially Posidonius as its principal representatives (...), in contrast to what Zeno and his immediate followers thought, it seems that not only the good people, but everyone was supposed to belong to this kosmopolis». Cf. Van Oort (1991: pp. 249-251). The idea of the cosmic city finds its roots in Platonism and is also developed by Aristotelianism.

16 Cf. Phil. De prov. 2.90 Cetera vero habentne providentiae congruentem rationem, quae videlicet in damnum hominum solent coalescere? (...) Nota est quae sub bello Peloponnesiaco pestis fuit, quae a Thucydide refertur; tum plures vix memorandae umquam morborum species novitatem redolentes.

17 Cf. Phil. De prov. 1.17-19 Cum enim, ut ostendi, partes mundi per destructionem corrumpi videam, cur non maiores quoque et ipsa elementa, caelum, inquam, et terram, destruenda fore concedam, cum iam de partium corruptione omnes consentiant? (...). Agam luculentissime de terra atque de aere, non minus ipsam aeris naturalem affectionem considerans, quam animadvertens ipsum nunc varias passiones experiri, et rursus in sanitatem redire.

18 Cf. Gale (1994: p. 225).

19 Here, I follow Bockemueller transposition of 1247-1251 to the conclusion of Book 6. Cf. P. Fowler (1997: pp. 112-114).

20 «It was impossible to find anyone who was not affected at that terrible time by disease or death or distress».

21 As regards Lucretius' use of this rethorical device, cf. Herrnstein Smith (1968: p. 183): «When universals and absolutes (words such as "all", "none", "only" and "always") occur in assertions, they are themselves the expression of the speaker's inability or refusal to qualify. And we may add superlatives to this category for they have the same expressive effect. To speak of what is "highest", "last", "best", or "most", is, of 
image. ${ }^{22}$ Thus, the end of the City becomes a perfect trait d'union between the scenes of cosmic ruin at the conclusion of Book 1 and Book 2 and the "triumphs of individual death" (and time) at the conclusion of Book 3 and Book 4.

\section{The sources of this device and the reasons of Lucretius' reinterpretation}

Lucretius is not the creator of the literary device of the "apocalyptic ending". In fact, we can trace back to the Iliad the practice of opening or closing a book with the description of a violent phenomenon, which breaks (or menaces to break) the natural order. These scenes can be object of direct description - like Zeus' terrible thunder in $\mathrm{Il}$. 7.478-481 - or included in a simile, like the fire imagery associated with Achilles' rage in 20.490-494. ${ }^{23}$ However, the most noticeable example is the opening scenario of Book 20 , which culminates with the suggestion of a "Theomachic" conflict «on a cosmic scale» (vv. 54-74). ${ }^{24}$ It is no wonder that the unknown author of the Greek treatise On the Sublime will quote these Homeric verses as a perfect example of "eschatological" sublime, representing the breaking of cosmic order, which threatens to revert to Chaos. ${ }^{25}$

"Apocalyptic conclusions" can be found also in Attic tragedy: surely, a clear example is the final scene of the pseudo-Aeschylean tragedy Prometheus Bound (vv. 1080-1090). Here, the Titan is overwhelmed by a cataclysm (earthquake, lightning, thunder and storm) that will bury him for generations. ${ }^{26}$

Among the possible sources of Lucretius' eschatological endings, we can also include Plato's dialogues. In fact, it is known that some of the major Platonic dialogues (the Gorgias, Phaedo and Republic) ${ }^{27}$ end with a myth, that is a "final revelation" (i.e. an

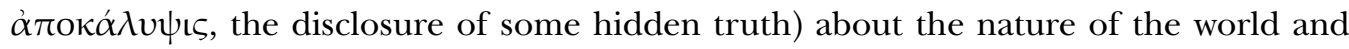
the destiny of man. ${ }^{28}$ As Nicholas Lévy points out, ${ }^{29}$ these transcendental meditations will exert a strong influence on Latin literature, from Cicero's Somnium Scipionis to Pythagoras' speech in Ovid's Metamorphoses, Book 15. ${ }^{30}$

course, also to assert extremities, absolutes, and ultimates. All such non-qualifying words and phrases tend to have closural effect when they occur as terminal features (...)».

22 Cf. Galzerano (2015: pp. 243-253).

23 As for the eschatological implications of this representation of Achilles cf. Chaudhuri (2014: pp. 27-30).

24 Cf. Yasamura (2011: p. 71).

25 See ps. Long. Subl. 9.6. Cf. Porter (2016: pp. 164-166).

26 Cf. Ruffel (2012: p. 94).

27 Cf. Republic X 614b-621c, Gorgias 523a-527b, Phaedo 109a-114d.

28 Cf. Clay (2000: p. 172).

29 Cf. Lévy (2014).

30 In this sense, Lucretius' closural catastrophes can be related to Lévy's category of the "révélation finale". In fact, like Lévy's “final revelation”, Lucretius' eschatological endings can be considered as a «configuration particulière de la fin», characterised by both a synthesis and a retrospective illumination («élucidation finale») of the main themes of the book (or the section). Moreover, they are also based on the rhetorical device of amplificatio, that is employed to persuade the readers through the arousal of feelings. Of course, 
In all the above-mentioned examples, the closing position of apocalyptic scenes seems due to a rhetorical intent. As it is said in Aristotle's Rhetorics (3.19 1419b10-25), the conclusion is a special place, dedicated both to recapitulate and to arouse the public's emo-

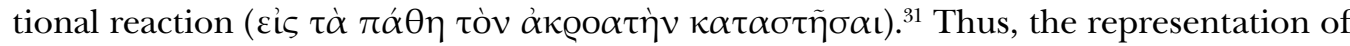
a cataclysm becomes a perfect means to captivate the readers, making them sympathetic with the victims of the catastrophe and willing to accept the author's message. ${ }^{32}$ In particular, the above-mentioned passages - as well as Lucretius ${ }^{\prime 33}$ - can be associated also with the device of the $\varphi \alpha \nu \tau \alpha \sigma i \alpha$ เ (or visiones), a particular technique of final demonstration. The use of $\varphi \alpha v \tau \alpha \sigma i \alpha \mathrm{t}$ aims at representing a phenomenon in a vivid way, from a close viewpoint: $:^{34}$ thus, the reader could live the cataclysm as if he were in the middle of it. ${ }^{35}$

The scheme of the final catastrophe is well attested before the De rerum natura. ${ }^{36}$ However, Lucretius takes full advantage of it, transforming it into a pervasive and dominant motif in his poem. We can explain this peculiar feature of Lucretius' De rerum natura in two ways. On the one hand, it is necessary to underline the importance of the cosmic mortality doctrine in Epicureanism, especially after the triumph of the Aristotelian theory according to which the cosmos and the biological species are eternal. In Lucretius' eyes, the interitus mundi is not only a literary topos, but a fundamental physical truth, the

unlike Lévy's examples, Lucretius' final revelations are reached through a particular type of divine inspiration, due to Epicurus' "divine" teachings (cf. DRN 5.8 deus ille fuit).

31 As regards the conclusion (epilogus, peroratio or conclusio) see also Cic. De orat. 2.332 omnia autem concludenda plerumque rebus augendis vel inflammando sunt iudice vel mitigando; omniaque cum superioribus orationis locis tum maxime extremo ad mentes iudicum quam maxime permovendas et ad utilitatem nostram vocandas conferenda sunt. In fact, as Quintilian highlights, the epilogus leverages both res and adfectus to reach the captatio benevolentiae. Cf. Quint. 5.1.1 eius duplex ratio posita aut in rebus aut in adfectibus.

32 Cf. Abry (2006: pp. 658-659): «Assurément ces images, par l'ampleur et le sublime qui leur sont inhérents, trouvent naturellement leur place dans une ouverture ou en conclusion d'un texte grave et douloueux. (...) Ces visions d'anéantissement par le feu ou par l'eau faisaient assurément partie des ressources à la disposition des rhéteurs et des poètes pour terminer de façon grandiose».

33 As regards the presence of rhetorical elements in Lucretius' poem, cf. Classen (1968: pp. 366-392); Asmis (1983: pp. 36-66); Schiesaro (1987: pp. 29-61); Schiesaro (2007: pp. 63-90). As Schiesaro (1987: p. 41) points out, «Con i caratteri del discorso forense il programma lucreziano coincide pressoché integralmente. Persuadere è per entrambi lo scopo essenziale, non un esercizio psicagogico senza implicazioni reali, ma missione (professionale e morale) sentita in prima persona dall'autore».

34 Cf. Quint. 6.2.29 XXIX At quo modo fiet ut adficiamur? Neque enim sunt motus in nostra potestate. Temptabo etiam de hoc dicere. Quas phantasias Graeci vocant (nos sane visiones appellemus), per quas imagines rerum absentium ita repraesentantur animo ut eas cernere oculis ac praesentes habere videamur, has quisquis bene ceperit is erit in adfectibus potentissimus.

35 This technique of representation can be also related with the rhetorical device variously labelled as $d e-$

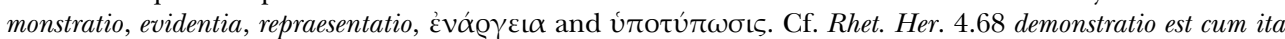
verbis res exprimitur ut geri negotium et res ante oculos esse videatur. Id fieri poterit si quae ante et post et in ipsa re facta comprehendemus. See also Cic. De or. 3.202 sub aspectum paene subiectio; Cic. orat. 139 subiciet oculis; Cic. part. 20 rem constituere paene ante oculos; Cic. top. 97 narrationes evidentes, and Quint. 4.2.63; 6.2.32; 8.3.61. As for úंotú $\pi \omega \sigma \iota \varsigma, \mathrm{cf}$. Quint. 9.2.20.

36 Cosmic eschatological scenes probably played an important role also in Latin archaic poetry, but, unfortunately, they survive only in fragmentary form. As regards Lucretius' contemporaries, Cicero's early translation of Aratus' poem shows an interesting incipitary reference to the philosophical "Gigantomachy" about the mortality of the world: cf. Cic. Arat. fr. 2 Buescu. The motif of cosmic mortality probably pervaded also Varro's Menippean Satires; cf. Galzerano (2015: pp. 252-253). 
inevitable destiny of our world. On the other hand, Lucretius' obsession with cosmic eschatology can be explained by the concept of sublime that «also lies at the heart of the poem's conception». ${ }^{37}$ In fact, like Longinus, Lucretius is manifestly fascinated by apocalyptic scenarios and employs their extraordinary impact to get his readers emotionally involved. Thus, the eschatological sublime is used to awake in the readers' soul the need of the Epicurean truth. In effect, Lucretius usually depicts the end of the world from the point of view of a spectator that does not understand the reasons of the catastrophe: this device allows the poet to invite his public to gain a cosmic viewpoint, from which it is possible to contemplate the naufragium of our world without care. Paradoxically, the sublime becomes a means to reach the absence of wonder. ${ }^{38}$

\section{Lucretius' "apocalyptic heritage"}

Indeed, as Ovid points out (see Amor. 1.15.23-24 and Trist. 2.425-426), the rational "prophecy" of a cosmic catastrophe was soon considered as an essential message in Lucretius' De rerum natura. Therefore, it is no wonder that, starting from the poets of the Augustan age, Latin authors will often reveal their debt to Lucretius' literary model in their eschatological passages. In particular, in this chapter we will see some significant examples in epic or didactic poetry, where the device of the eschatological ending is employed with reference to Lucretius' eschatological auctoritas.

\section{The final episode of Virgil's Georgics Book 1}

Virgil's Georgics Book 1 ends with the description of the upsetting and extraordinary phenomena suffered by Italy after Julius Caesar's death. This section represents a great "apocalyptical" scenario, culminating with the triumph of war and chaos, and is pervaded by references and allusions to Lucretius' eschatological passages. First, the depiction of Aetna's eruption (1.471-473):

quotiens Cyclopum efferuere in agros

vidimus undantem ruptis fornacibus Aetnam,

flammarumque globos liquefactaque volvere saxa! ${ }^{19}$

Virgil quotes Lucretius' treatment of volcanoes - and particularly of Aetna - in Book $6,{ }^{40}$ but he also recalls $1.722-725$, where the Aetna imagery is associated with the escha-

37 Cf. Porter (2007: pp. 176-178).

38 As regards this paradox, cf. Gale (2000: pp. 198-200). The contemplation of a negative attitude towards catastrophe leads Lucretius' readers to understand their own spirit and, ultimately, to find peace of mind. This device can be interpreted as a sort of Epicurean eschatological catharsis.

39 «How frequently we've watched eruptions of Mount Etna and the expulsions from her furnaces spill on the one-eyed giants' lands fireballs and molten lava!». Translation by Peter Fallon, which will be used throughout.

40 Cf. DRN 6.639-711 passim. Nunc tamen illa modis quibus inritata repente / flamma foras vastis Aetnae fornacibus efflet / expediam (...) Hic ubi percaluit cale fecitque omnia circum / saxa furens, qua contingit, terramque et ab ollis / excussit calidum flammis velocibus ignem, / tollit se ac rectis ita faucibus eicit alte. 
tological myth of Typhaeus and, symbolically, with Empedocles' doctrines about the end of the world.

Virgil alludes to Lucretius also in the last scene of Book 1, which represents the triumph of Mars and the victory of chaos (vv. 511-514). In fact, as noted by Monica Gale and Catherine Ware, Virgil's Mars is «clearly a Phaeton figure». ${ }^{41}$ Therefore, the first Book of Virgil's poem ends up with a Lucretian quotation ${ }^{42}$ and describes a political crisis of Rome as the end of the world. ${ }^{43}$

(...) saevit toto Mars impius orbe, ut cum carceribus sese effudere quadrigae, addunt in spatia, et frustra retinacula tendens fertur equis auriga neque audit currus habenas. ${ }^{44}$

\section{The final scene of Manilius' Astronomica, Book 1}

Numquam futtilibus excanduit ignibus aether: squalidaque elusi deplorant arva coloni, et sterilis inter sulcos defessus arator ad iuga maerentis cogit frustrata iuvencos. aut gravibus morbis et lenta corpora tabe corripit exustis letalis flamma medullis labentisque rapit populos, totasque per urbes publica succensis peraguntur fata sepulcris. qualis Erechtheos pestis populata colonos extulit antiquas per funera pacis Athenas. ${ }^{45}$

41 Cf. Gale (2000: p. 35) and Ware (2012: p. 133).

42 Cf. 5.396-401 ignis enim superavit et ambiens multa perussit, / avia cum Phaethonta rapax vis solis equorum / aethere raptavit toto terrasque per omnis. / At pater omnipotens ira tum percitus acri / magnanimum Phaethonta repenti fulminis ictu / deturbavit equis in terram. Cf. also DRN 2.263-265 nonne vides etiam patefactis tempore puncto / carceribus non posse tamen prorumpere equorum / vim cupidam tam de subito quam mens avet ipsa?

43 It is important to notice that these quotations and allusions to Lucretius seem to refer also to Empedocles' eschatological doctrines, as if the Epicurean poet were Empedocles' Latin heir. The connection of Lucretius' poem with the Empedoclean model is stressed even in Cicero's review (ad Q. fr. 2.9 [11]), where Lucreti poemata are connected (although contrastively) with Sallusti Empedoclea.

44 «The whole world's at loggerheads, a blasphemous battle, as when, right from the ready, steady, go, chariots quicken on a track until the driver hasn't a hope of holding the reins and he's carried away by a team that pays heed to nothing, wildly away and no control».

45 «For the fires wherewith the heavens blaze have never lacked significance, but farmers, cheated of their hopes, mourn over blighted fields, and amid barren furrow's the weary ploughman vainly urges to the yoke his drooping team. Or else, when grievous sickness and a slow decline has gripped men's bodies, a mortal flame bums out the seat of life and sweeps away the stricken peoples; and the obsequies of the community fill whole cities with blazing pyres. Such was the plague which ravaged Erechtheus' folk and bore forth ancient Athens to an unwarlike grave, when, one after another, men collapsed upon the dead and died: no place was there for a doctor's skill, no prayers availed; duty fell a prey to sickness, and none were left to bury, none to weep the dead ; the wearied fires sufficed not for their office, and limbs piled on limbs the corpses burnt: hardly was an heir to be found in that nation once so vast». Translation by G. P. Goold, which will be used throughout. 
In the apocalyptic final scenario of the Book 1 of his Astronomica, Manilius pays tribute to Lucretius' most famous eschatological endings, i.e. the conclusions of Book 2 and of Book $6 .{ }^{46}$ In fact, vv. 876-879 represent the useless efforts and the desperation of a farmer (defessus arator), because of the sterility of the Earth: this is a manifest reformulation of Lucretius' desperate farmers (grandis arator and vitis sator) at the conclusion of Book 2.

Analogously, Manilius' vv. 880-891 are a clear homage to Lucretius' picture of the Athenian plague. Like Lucretius, Manilius proposes an eschatological interpretation of the plague: the catastrophe represents a real "illness" of the world and of nature, which causes the ruin of everything (1.894-895): cum mundus et ipsa / aegrotet natura, hominum sortita sepulcrum. ${ }^{47}$

\section{The final scene of Manilius' Astronomica, Book 5 \\ Sunt stellae procerum similes, sunt proxima primis \\ sidera, suntque gradus atque omnia iusta priorum: \\ maximus est populus summo qui culmine fertur; \\ cui si pro numero vires natura dedisset, \\ ipse suas aether flammas sufferre nequiret, \\ totus et accenso mundus flagraret Olympo. ${ }^{48}$}

As demonstrated by J. H. Aubry, ${ }^{49}$ vv. $742-745$ of Manilius' Book 5 probably represent the real conclusion of the Astronomica. Manilius maintains the Aristotelian theory of the eternity of the world, inherited by the Middle Stoa (firstly, Boethus and Panaetius). ${ }^{50}$ Therefore, his choice of concluding his work with a "false" eschatological scenario is clearly due to his desire of reaffirming his opinion against his adversaries, ${ }^{51}$ utterly excluding the possibility of a cosmic catastrophe. ${ }^{52}$ However, this particular eschatological scenario - presented as the immediate consequence of a wrong theory of the universe - also recalls the conclusion of the first book of De rerum natura, where Lucretius de-

46 However, it should be noted that Manilius uses Lucretius' closural device to achieve the opposite effect: in fact, while Lucretius strives to underline the mortality of the world and the absence of providence, Manilius confirms the providential order of the cosmos, where nothing happens by chance. Cf. 1.876 numquam futtilibus excanduit ignibus aether.

47 «Since heaven and nature's self are stricken and seem doomed to share men's tomb».

48 «There are all the grades and privileges of superior orders. But outnumbering all these is the populace which revolves about heaven's dome: had nature given it powers consonant with its legions, the very empyrean would be helpless before its fires, and the whole universe would become embroiled in the flames of a blazing sky».

49 Cf. Abry (2006: pp. 657-666).

50 Cf. Phil. Alex. De aeternitate mundi $76 \mathrm{ff}$.

51 Manilius is clearly confuting the original Stoic theory of $\varepsilon \kappa \tau u ́ \varrho \omega \sigma \iota \varsigma$, reasserting the middle-Stoic (Panaetian) doctrine of cosmic eternity.

52 Notwithstanding, it must be noted that Manilius denies the reality of his eschatological scenario, but clearly takes advantage of its sublime emotional power. As Abry (2006: p. 666) highlights, «néanmoins, l'idée, récurrente, trahit chez Manilius une forme d'angoisse cosmique qui annonce celle de Sénèque». Cf. also the hypothetical eschatological scenario in 2.804-807 and Lapidge's commentary (Lapidge 1989: pp. 1379-1429). 
scribes the end of the world as consequence of a Stoic geocentric theory (probably the same defended by Manilius). ${ }^{53}$ Thus, both Lucretius and Manilius choose an hypothetical cosmic cataclysm as the conclusion for their books, taking advantage of the same eschatological imagery with opposite intents. The demonstration of the profound connection between the eschatological conclusions of Manilius' Book 5 and Lucretius' Book 1 can be interpreted as another relevant proof in favour of the interpretation of 5.742-745 as the conclusion of Manilius' poem.

\section{The final scene of Statius' Thebaid, Book 7}

In the last scene of Statius' Thebaid Book 7, ${ }^{54}$ a frightful chasm (ingens specus) devours the Argive hero Amphiaraus and drags him down to the underworld (in Tartara). Eschatological imagery pervades the scene: the hero's death coincide with the ruin of the world. Statius clearly quotes Lucretius' poem in vv. 812-813, when he foresees the collapse of the sky, defined as machina caeli, a reformulation of Lucretius' description of the ruin of the machina mundi (DRN 5.91-96 multosque per annos / sustentata ruet moles atque machina mundi). However, Statius' homage to Lucretius is wider and could be extended to vv. 809-817: in fact, the poet builds this passage on the Epicurean technique of the multiple causes ${ }^{55}$ (vv. 812-813).

\section{Conclusion}

Our exam of the above-mentioned passages clearly demonstrates the wide range of influence of Lucretius' eschatological conclusions. Lucretius casts his shadow over the most important "apocalyptic" scenarios in Latin literature. Even though Lucretius' ideological intent is reversed and the Lucretian sublime is used to deny the possibility of a cosmic catastrophe and to celebrate the eternal stability of the world, the destabilizing power of the Epicurean poet does not utterly disappear. Lucretius' eschatological message, even when it is apparently reduced to a literary motif, succeeds in maintaining a part of its "subversive" nature: thus, it resembles the poet's description of Typhoeus, who keeps menacing to escape his prison and to plung again the world into chaos (DRN 1.722-725):

Hic est vasta Charybdis et hic Aetnaea minantur

murmura flammarum rursum se colligere iras,

53 Of course, Lucretius is not the only source for this eschatological ending. It is noteworthy that the last word of Manilius' poem (Olympo) stands out also in the conclusion of Virgil's Georgics (4.562), with reference to Augustus' triumph.

54 Statius was very conscious of Lucretius' eschatological authority, so he often pays tribute to the Epicurean poet. Cf. his enthusiastic praise in Silv. 2.7.76 et docti furor arduus Lucreti.

55 Cf. Hardie (2008: pp. 69-96). There may be another Lucretian allusion also in the eschatological ending of Book 10: in fact, as Chaudhuri (2014: pp. 268-297) demonstrates, there's a strong symbolic relation between Capaneus' attempted revival of the Gigantomachy, and Lucretius' representation of Epicurus as a victorious giant, with «a reversal of its hubristic connotations». 
faucibus eruptos iterum vis ut vomat ignis

ad caelumque ferat flammai fulgura rursum..$^{56}$

\section{Bibliography}

Abry, J. H. (2006). Les vers 710-745 sont-ils l'épilogue des Astronomiques? In B. Bureau, \& C. Nicolas, Commencer et finir. Débuts et fins dans les littératures grecque, latine et néolatine. Actes du colloque organisé les 29 et 30 septembre 2006 par l'Université Jean Moulin - Lyon 3 et l'ENS - LSH, Lyon 2006 (pp. 657-666). Lyon: Université Lyon III Jean Moulin.

Asmis, E. (1983). Rhetoric and Reason in Lucretius. American Journal of Philology, 104, 36-66.

Bakker, F. A. (2016). Epicurean Meteorology: Sources, Method, Scope and Organization. Leiden: Brill.

Brown, R. D. (1987). Lucretius on Love and Sex. Leiden: Brill.

Chaudhuri, P. (2014). The War with God: Theomachy in Roman Imperial Poetry. Oxford: Oxford University Press.

Classen, C. J. (1968). Poetry and Rhetoric in Lucretius. Transactions of the American Philological Association, 99, 366-392.

Clay, D. (2000). Platonic Questions, Dialogues with the Silent Philosopher. University Park, Pa: The Pennsylvania State University Press.

Fallon, P. (Transl.). (2006). Vergilius: Georgics. Oxford: Oxford Univ. Press.

Fowler, D. (1997). Second Thoughts on Closure. In D. H. Roberts, F. M. Dunn, \& D. Fowler (Eds.), Classical Closure: Reading the End in Greek and Latin Literature (pp. 3-22). Princeton: Princeton University Press.

Fowler, D. (2000). First Thoughts on Closure. In D. Fowler, Roman Constructions: Readings in Postmodern Latin (pp. 284-307). Oxford: Oxford University Press.

Fowler, P. (1997). Lucretian Conclusions. In D. H. Roberts, F. M. Dunn, \& D. Fowler (Eds.), Classical Closure: Reading the End in Greek and Latin Literature (pp. 112-138). Princeton: Princeton University Press.

Gale, M. (1994). Myth and Poetry in Lucretius. Cambridge: Cambridge University Press.

Gale, M. (2000). Virgil on the Nature of Things. The Georgics, Lucretius and Didactic Tradition. Cambridge: Cambridge University Press.

Galzerano, M. (2015). Lucrezio, De rerum natura 2, 1173-1174, in difesa di "ire ad capulum". Paideia. Rivista di Filologia, Ermeneutica, Critica Letteraria, 70, 243-253.

Goold, G. P. (Transl.). (1997). Manilius: Astronomica. Cambridge: Harvard Univ. Press.

Hardie, P. (1997). Closure in Latin Epic. In D. H. Roberts, F. M. Dunn, \& D. Fowler (Eds.), Classical Closure: Reading the End in Greek and Latin Literature (pp. 139-162). Princeton: Princeton University Press.

Hardie, P. (2008). Lucretian Multiple Explanations. In M. Beretta, \& F. Citti (Eds.), Lucrezio, la natura e la scienza (pp. 69-96). Firenze: Olschki.

Herrnstein Smith, B. (1968). Poetic Closure. A Study of How Poems End. Chicago: The University of Chicago Press.

56 «Here is yawning Charybdis; here rumbling Etna threatens to reassemble her angry flames in readiness to belch fire from her throat in another violent eruption and once more shoot to the sky flakes of flame». 
Klingner, F. (1952). Philosophie und Dichtkunst am Ende des zweiten Buches des Lukrez. Hermes, 80, 3-30.

Lapidge, M. (1989). Stoic Cosmology and Roman Literature. Aufstieg und Niedergang der römischen Welt II, 36(3), 1379-1429.

Lehoux, D. (2013). Seeing and Unseeing, Seen and Unseen. In D. Lehoux, A. D. Morrison, \& A. Sharrock (Eds.), Lucretius: Poetry, Philosophy, Science (pp. 131-152). Oxford: Oxford University Press.

Lévy, N. (2014). La révélation finale à Rome. Ciceron, Ovide et Apulée. Paris: Presses de l'Université Paris - Sorbonne.

Müller, G. (1978). Die Finalia der sechs Bücher des Lukrez. In O. Gigon (Ed.), Lucrèce: huit exposés suivis de discussions. Vandoeuvres, Genève, 22-27 aô̂t 1977 (pp. 197-231). Genève: Fondation Hardt.

Porter, J. I. (2007). Lucretius and the Sublime. In M. Gale (Ed.), The Cambridge Companion to Lucretius (pp. 176-178). Cambridge: Cambridge University Press.

Porter, J. I. (2016). The Sublime in Antiquity. Cambridge: Cambridge University Press.

Ruffel, I. (2012). Aeschylus: Prometheus Bound. London: Bristol Classical Press.

Schiesaro, A. (1987). Lucrezio, Cicerone, l'oratoria. Materiali e discussion per l'analisi dei testi classici, 19, 29-61.

Schiesaro, A. (2007). Didaxis, Rhetoric, and the Law in Lucretius. In S. J. Heyworth (Ed.), Classical Constructions: Papers in Memory of Don Fowler, Classicist and Epicurean (pp. 63-90). Oxford: Oxford University Press.

Segal, C. (1990). Lucretius on Death and Anxiety. Princeton: Princeton University Press.

Smith, M. F. (Transl.). (2001). Lucretius: On the nature of things. Indianapolis: Hackett.

Van Oort, J. (1991). Jerusalem and Babylon. A Study into Augustine's City of God and the Sources of His Doctrine of the Two Cities. Leiden: Brill.

Ware, C. (2012). Claudian and the Roman Epic Tradition. Cambridge: Cambridge University Press.

Yasamura, N. (2011). Challenges to the Power of Zeus in Early Greek Poetry. London - New York: Bloomsbury Academic.

Dott. Manuel Galzerano / manuel.galzerano@uniroma3.it

Doctor of Philosophy in Graeco-Roman Civilization and Tradition

Department of Humanities

Roma Tre University

Via Ostiense 234, 00146 Roma (Rm), Italia 
